\title{
Emergence of Women-Owned SMEs as a Game-Changer of Malaysia in the Era of Digitalization
}

\author{
Arijita Dutta $^{{ }^{*}}$, Sharmistha Banerjee ${ }^{2}$, Olivia Sarkar ${ }^{3}$, Arkadipta Roy ${ }^{4}$, \\ Ashish Kumar Sana ${ }^{5}$ and Sudeshna Basu Mukherjee ${ }^{6}$ \\ ${ }^{1}$ Professor, Department of Economics, ${ }^{2}$ Professor, Department of Business Management \\ ${ }^{3 \& 4}$ Project Fellow, UGC UPE II, ${ }^{5}$ Professor, Department of Commerce, ${ }^{6}$ Professor, Department of Sociology \\ ${ }^{1,2,3,4,5 \& 6}$ University of Calcutta, Kolkata, West Bengal, India \\ *Corresponding Author \\ E-Mail: dutta.arijita@gmail.com
}

\begin{abstract}
Given the current constraints of the Malaysian economy to grow beyond the middle-income trap, the women owned small and medium enterprises are envisioned to be the game changers, to lead the Malaysian economy out of the middle-income trap. While the microenterprises owned by women are expected to bring in more inclusiveness and gender-parity in the economy, the small ventures can feed in the big business to act as an enabler of growth, and the medium enterprises have the potential to emerge as driver of growth themselves. The authors posit that classical constraints faced by women-owned SMEs, mostly rooted in resource crunch may be partially overcome by using the digitalized platform and e-commerce infrastructure of the country. However, state-level evidence suggests that majority of womenowned SMEs (WOSME) belong to micro and small sectors, with limited ability of job creation. Also, the presence of medium firms is highly skewed towards traditional lowtechnology sectors, in spite of educational and technical exposure. The success of these WOSME is actually dependent on the nature of the big business and the state-level economic and social characteristics, rather than the utilization of digital platforms by SMEs. This supports the evidence that success of WOSME is still heavily dependent on the large business enterprises, representing the classical structure. Absence of any effective policy to encourage women SME entrepreneurs in Malaysia constricts WOSMEs from playing the role of game-changer in the digitalized economy, in spite of their extremely high potential. Policies in the country appeared to be ethnicity-conscious, rather than gender-centric.

Keywords: Small and Medium Enterprises (SMEs), Women Entrepreneurs, Digitalization, E-Commerce Productivity, Value Added By, Manufacturing and Services, OLS

JEL Classification: L52, L60, L86, J16
\end{abstract}

\section{INTRODUCTION}

Small and Medium Enterprises (SME) are key players in majority of global economies in the wider eco-system of firms. Though traditionally they used to be involved in handicrafts and cottage-based industries mostly for local markets, more matured levels of globalization has identified the importance of enabling them to adapt and thrive in an open environment and participate more actively in the digital transformation for boosting inclusive economic development. However, boosting SME potential for participating in and reaping benefits of a globalised and digital economy depends to a great extent on the incidence of the conducive environment, existing policy framework and healthy competition in inter- and intra-country regions. SMEs' contributions also depend on their access to strategic resources, such as skills, knowledge networks, and finance, and on public investments in areas such as education and training, innovation, technological connectivity and infrastructure.

Innovation among SMEs activities too have increased in recent decades, as newer products, more niched market and continuously changing technologies have enabled SMEs to strengthen their comparative advantages and reduce their structural disadvantages stemming from resource constraints and limited ability to reap economies of scale. The digital transition facilitates the emergence of "born global" small businesses and provides new opportunities to leverage their competitiveness in both local and global markets. It also facilitates the emergence of "lean start-ups" that influence the internet to lower fixed costs and outsources many aspects of the business to stay agile and responsive to the market (OECD 2017).

In the OECD area, SMEs are the predominant form of enterprise, accounting for nearly $99 \%$ of all firms. They provide $70 \%$ of employment, and $50 \%-60 \%$ of value added on an average (OECD, 2016). In emerging economies, SMEs contribute up to $45 \%$ of total employment and $33 \%$ of GDP, while considering the informal businesses into account, the corresponding shares move up to $50 \%$ in both cases (IFC, 2010). Globally, micro-enterprises (up to 9 employees) dominate the business landscape, accounting for $70 \%$ to $95 \%$ of all firms. According to Eurostat (2014), SMEs own $20 \%$ of all patents in OECD countries, hinting their ability to reap unconventional avenues of business strategies and their innovative capacity. SME's contribution to employment varies across sectors. In services, SMEs account for $60 \%$ or more of total employment and value added (VA) in nearly all countries. In contrast, in manufacturing, although relatively few in number, large firms offer a disproportionate contribution to employment and value added, reflecting increasing returns to scale from more capital-intensive production, as well as entry barriers related to investment. 
Failures in financial markets, due to asymmetric information and agency problems, typically limit access to credit by SMEs and start-ups, which are often undercollateralized, and may lack the expertise needed to produce sophisticated financial statements (OECD, 2013). This is an area where the case for policy intervention to repair these failures is well recognized. Credit constraints are especially severe in mid- and low-income countries, where funding gaps are often the main barrier to formalization and SME development. Thus within the complex policy framework to support SMEs, the national governments must focus on access to credit, skill enhancement and digital infrastructure to enable them to reap the benefits of more inter-connected global markets.

Within the SME sector, women owned SMEs (WOSME) additionally serve avenues for social and economic empowerment of women, a crucial issue in terms of SDGs. The Global Entrepreneurship Monitor (GEM) (2012) reported that in 67 economies around the world, there were 126 million women who were engaged in entrepreneurial ventures and employed at least one person in running the business. US Census Bureau (2014) found that from 1997 to 2014, the number of businesses owned by women have increased from $47 \%$ to $68 \%$. Based on the findings from the IFC's Enterprise Finance Gap Assessment Database (2012), it is estimated that globally there are roughly 9.34 formal million women-owned SMEs in over 140 assessed countries, which is approximately one third of all formal SMEs with East Asia and the Pacific having the highest overall number.

The credit gap for formal women-owned SMEs across all regions is roughly $\$ 2872$ billion, which is 30 percent of the total credit gap for SMEs. Latin America and the Caribbean have the largest credit gap, followed by East Asia and the Pacific and Europe and Central Asia, identifying suboptimal utilization of women entrepreneurs to boost growth. This critical lacuna in infrastructure supporting women SMEs deprives the world from harnessing the potential of half its populace. With adequate support in promoting women SME, these entrepreneurs can increase their economic decision making power and ability, sense of worth (economic efficacy and self-confidence), own assets in terms of income, property, saving and capital (access to economic resources) and enhance necessary knowledge and skills to run their own business (capacity). Women who are engaged in their businesses with a goal that goes beyond just earning money become role models and a beacon of empowerment for other aspiring women to thrive in this competitive male dominated world.

Most of the financial and non-financial barriers affecting WOSMEs play major blockades at the startup stage of the business life cycle. Although access to finance is one of the major constraints, it cannot be looked at in isolation from the other barriers which heavily impact women-owned enterprises. The most significant barriers tend to be nonfinancial in nature, influencing the degree to which
WOSME can formally access financial products and services and realize the growth potential of their enterprises. In comparison to men, women generally face a disproportionately larger number of challenges when applying for credit as also in financial decision making. Financial barriers include local financial conditions-such as a lack of collateral, inadequate financial infrastructure, or the high cost of funding - while non-financial barriers include the social and cultural norms underlying gender biases, as well as the tendency for women-owned SMEs to be smaller in size, restricted to traditional sectors and the limited access to business education opportunities and networks. Society is often not open to allow women to take entrepreneurial risks and thwarted to exploit their full potential. Also, women are expected to engage in enterprises with extremely low innovation content, so that it does not disrupt the traditional female roles of household chores (Rankin, 2002). Risk averse and non-innovative business ventures of WOSME themselves remain partially embedded in socio-cultural framework of the economy (Dutta \& Banerjee 2018).

Given that East Asia and Pacific is home to almost one third of the 10 million formal WOSME, this paper is focused on Malaysia and its WOSME. Malaysia is the $66^{\text {th }}$ largest country by land area and is a federation of 13 states. These are divided between two regions, with 11 states and two federal territories on Peninsular Malaysia and the other two states and one federal territory [Sabah, Sarawak and WP Labuan] in East Malaysia. Malaysian economy like any other economy in the world is heavily dependent on the performance of its Micro, Small and Medium Enterprises (SMEs) that occupies majority share in the country's total business entities. In terms of demography, the country is inhabited by Malays or Bumiputera, people with Chinese and Indian origin. The highest proportion of people with Chinese origin lives in W P KL and Penang and the least in Terengganu.

Representing $99.2 \%$ of the business community, SMEs in Malaysia are closely related to every facet of the economy microenterprises, the rural community, the bottom $40 \%$ of the income pyramid, suppliers to big businesses, endproducers, essentially making up a large portion of the private sector. In the last few years, SMEs have witnessed a marked improvement in their performance in Malaysia. Real Gross Domestic Product (GDP) of SMEs has consistently out-performed that of the overall economy, expanding at an average annual growth rate of $6.8 \%$ versus $4.9 \%$ for the overall economic growth in the period 2004 2010 (National SME Development Council, 2012). Surprisingly, not just growth rates in value added and employment generation, the productivity (defined as value added per employee) growth of SME sector (3.4\% annually) out-performed the overall economy (2.3\% annually) during the afore-said period, challenging the myth of lowproductive subsistence SME image. Since the current decade, the country, however, faces the predicament of a 'middle-income' trap as the historical growth engines have 
moderated. At the same time, the world economy is expected to converge to a 'new normal' where a more modest role is expected to be played by the advanced economies. These two internal and external forces can spawn new opportunities for countries like Malaysia, especially from intra-regional trade and investment.

This requires a 'game changer' or a new approach for a fundamental shift in the sources of Malaysia's competitive advantage from low-cost to high-value. Here, the role of SMEs will become increasingly critical, not only as enabler of growth by providing the support to large firms but also as a driver of economic growth by themselves. While the micro-enterprises emerging from the Bottom 40 income earners can offer a balanced growth for the Malaysian economy through its inclusiveness, the Middle 40 (Medium \& Small) enterprises are poised to play the role of an enabler of growth by virtue of supporting the big business sector.

The Top 20 medium enterprises, often unleashing their advantages in high-tech skill-dependent ventures in digitalized platforms, can themselves offer a significant role as driver of growth (National SME Development Council, 2012). This partially marks a departure from common SME perspectives in other developing countries with low digitalization. It is normally the medium strata of this sector gets engaged in linkages with large firms where the latter remains the source of all information, business development and innovation, while medium firms thrives mostly as parasites on them (Francisco \& Canare 2018).

Meanwhile, it is not unfounded that the advancement of internet connectivity and digital transition has the potential to unlock untapped opportunities for SMEs to achieve higher degrees of accomplishment. Therefore, digitalization has become one of the core focus areas in Malaysia through which the economy aims to achieve the target of being considered as a “Developing Country” by 2020.

In 2015, women-owned SMEs accounted for 186,930 firms or about 20.6\% of total SMEs in Malaysia (2010: 127,429 firms). There was an increase of $46.7 \%$, from the one recorded in 2010. In terms of breakdown by sectors, majority $92.7 \%$ of women-owned are SMEs engaged in the services sector, followed by the manufacturing sector (5.1\%).There is significant variation of WOSME participation across states and sectors. Given this background, the current study attempts to diagnose the nature and type of WOSME across regions and sectors in Malaysia and also to identify the enabling factors behind their success at the macro level. The paper would like to understand whether the WOSME is currently poised to assume the game changer role as outlined in policy briefs of the country.

\section{DATA AND METHODOLOGY}

The analysis in this paper is based on secondary data received from Department of Statistics, Malaysia in 2018. It provides detail state-level information on WOSME, overall SME and big business. State-specific demographic and economic information are collected from other public sources, including Census of Malaysia. Additionally, some information from primary data survey of leading women entrepreneurs in SME sector have been used for anecdotal evidence.

The methodology of the paper has been exploratory in nature, using descriptive statistics and simple statistical tools. The regression analysis uses OLS technique at state level. The presence of multicollinearity has been checked by VIF. Though the state-level analysis suffers from small sample size, its results can be used for identifying major correlates of success of WOSME, rather than offering definite confirmatory direction.

\section{RESULTS}

Before we move on to the analysis of SME and WOSME in Malaysia, we make a note of the definition of SME per se in the country. Given that there have been many developments in the economy since 2005 such as price inflation, structural changes and change in business trends, a review of the definition was undertaken in 2013 and a new SME definition was endorsed at the 14th NSDC Meeting in July 2013.

The definition covers all sectors, namely services, manufacturing, construction and mining \& quarrying. For the manufacturing sector, SMEs are defined as firms with sales turnover not exceeding RM50 million OR number of full-time employees not exceeding 200, while for the services and other sectors, SMEs are defined as firms with sales turnover not exceeding RM20 million OR number of full-time employees not exceeding 75 (Table I). Agriculture is merged with services and other sectors.

The new definition of SMEs provided for additional 8,120 establishments to be classified as SMEs, bringing the share of SMEs to total establishments from $97.3 \%$ to $98.5 \%$. The adoption of new official SME definition in 2014 has led to approximately 8,000 additional firms to be now categorized as SMEs (Chin \& Lim 2018) [1], which made these SME establishments eligible for government assistance. Similarly, the employees engaged in the SME sector also increased. However, even though more than half of the additional numbers of employees was from services sectors, the SME-GDP in the services sector did not record much change in 2014.

It may be observed that supporting the fact that $98.5 \%$ of total establishments in Malaysia are SMEs, the state-wise shares of SMEs in all business remains high in all states (ranging between 99.66 in Perils to 95.82 in Putrajaya). Corresponding shares of WOSME in all SMEs and their shares in Value Added (VA) in 2016 are presented below in Fig.1. 
TABle I Definitional Change Of Sme In Malaysia

\begin{tabular}{|c|c|c|c|c|c|c|}
\hline \multirow{2}{*}{ Category } & \multicolumn{2}{|c|}{ Micro } & \multicolumn{2}{|c|}{ Small } & \multicolumn{2}{|c|}{ Medium } \\
\hline & OLD & NEW & OLD & NEW & OLD & NEW \\
\hline \multirow[t]{2}{*}{ 莺总 } & $\begin{array}{l}\text { Annual sales } \\
\text { turnover Less than } \\
\text { RM200,000 }\end{array}$ & $*$ & $\begin{array}{c}\text { Annual sales } \\
\text { turnover between } \\
\text { RM200,000 \& } \\
\text { less than RM1 } \\
\text { million. }\end{array}$ & $*$ & $\begin{array}{l}\text { Annual sales } \\
\text { turnover between } \\
\text { RM1 million \& } \\
\text { RM5 million. }\end{array}$ & $*$ \\
\hline & $\begin{array}{l}\text { Less than } 5 \\
\text { employees }\end{array}$ & $*$ & $\begin{array}{c}\text { Between } 5 \text { \& } 19 \\
\text { employees. }\end{array}$ & * & $\begin{array}{c}\text { Between } 20 \text { \& } 50 \\
\text { employees. }\end{array}$ & $*$ \\
\hline \multirow{2}{*}{ 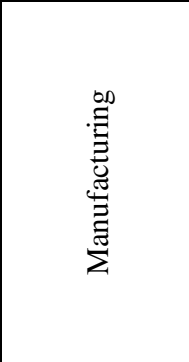 } & $\begin{array}{l}\text { Annual sales } \\
\text { turnover less than } \\
\text { RM250,000. }\end{array}$ & $\begin{array}{l}\text { Sales turnover } \\
\text { of less than } \\
\text { RM 300’000 }\end{array}$ & $\begin{array}{l}\text { Annual sales } \\
\text { turnover between } \\
\text { RM250,000\& } \\
\text { less than RM10 } \\
\text { million. }\end{array}$ & $\begin{array}{l}\text { Sales turnover } \\
\text { from M300,000 } \\
\text { to less than } \\
\text { RM15 million }\end{array}$ & $\begin{array}{l}\text { Annual sales } \\
\text { turnover Between } \\
\text { RM10 million \& } \\
\text { RM25 million. }\end{array}$ & $\begin{array}{l}\text { Sales turnover } \\
\text { from RM15 } \\
\text { million to less } \\
\text { than RM50 } \\
\text { million }\end{array}$ \\
\hline & $\begin{array}{l}\text { Less than } 5 \\
\text { employees. }\end{array}$ & $\begin{array}{c}\text { Full time } \\
\text { employees less } \\
\text { than } 5\end{array}$ & $\begin{array}{c}\text { Between } 5 \text { \& } 50 \\
\text { employees. }\end{array}$ & $\begin{array}{c}\text { Full-time } \\
\text { employees from } \\
5 \text { to less than } 75\end{array}$ & $\begin{array}{c}\text { Between } 51 \& \\
150 \text { employees. }\end{array}$ & $\begin{array}{c}\text { Full-time } \\
\text { employees } \\
\text { from } 75 \text { to not } \\
\text { exceeding } 200\end{array}$ \\
\hline \multirow{2}{*}{ 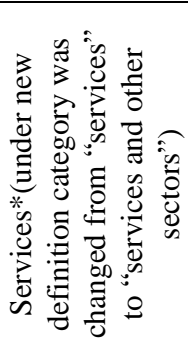 } & $\begin{array}{l}\text { Annual sales } \\
\text { turnover less than } \\
\text { RM200,000. }\end{array}$ & $\begin{array}{l}\text { Sales turnover } \\
\text { of less than } \\
\text { RM 300’000 }\end{array}$ & $\begin{array}{l}\text { Annual sales } \\
\text { turnover between } \\
\text { RM200,000 \& } \\
\text { less than RM1 } \\
\text { million. }\end{array}$ & $\begin{array}{l}\text { Sales turnover } \\
\text { from } \\
\text { RM300,000 to } \\
\text { less than RM3 } \\
\text { million }\end{array}$ & $\begin{array}{l}\text { Annual sales } \\
\text { turnover Between } \\
\text { RM1 million \& } \\
\text { RM5 million. }\end{array}$ & $\begin{array}{l}\text { Sales turnover } \\
\text { from RM3 } \\
\text { million to not } \\
\text { exceeding } \\
\text { RM20 million }\end{array}$ \\
\hline & $\begin{array}{l}\text { Less than } 5 \\
\text { employees. }\end{array}$ & $\begin{array}{c}\text { Full time } \\
\text { employees less } \\
\text { than } 5\end{array}$ & $\begin{array}{c}\text { Between } 5 \text { \& } 19 \\
\text { employees. }\end{array}$ & $\begin{array}{c}\text { Full-time } \\
\text { employees from } \\
5 \text { to less than } 30\end{array}$ & $\begin{array}{c}\text { Between } 20 \& 50 \\
\text { employees. }\end{array}$ & $\begin{array}{c}\text { Full-time } \\
\text { employees } \\
\text { from } 30 \text { to not } \\
\text { exceeding } 75\end{array}$ \\
\hline
\end{tabular}

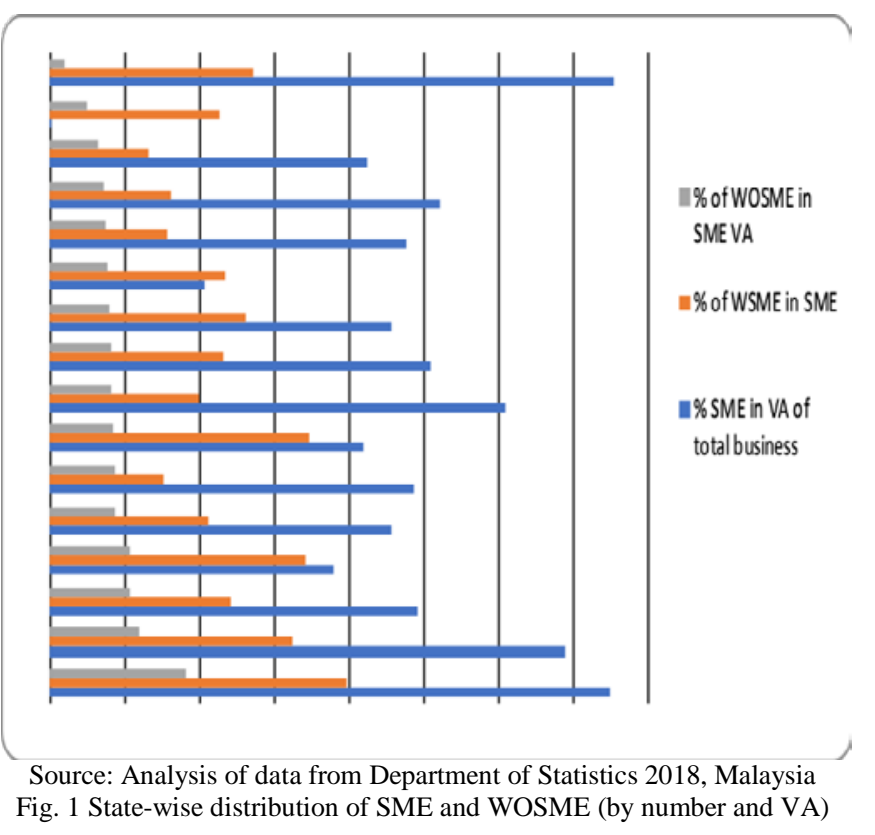

The highest share of WOSME among the SME in each state (indicated by the red bar) is observed in Kelantan (39.58\%), arguably one of the poorest regions of the country. It is followed by Terengganu and Sabah, states dominated by Malays, especially Bumiputera in the demography.

The states are famous for the handicrafts like batik. The share of value added (VA) by WOSME in VA by all SME (indicated by green bars) remains highest in Kelantan, while the second and third position is enjoyed by Perils and Kedah. It must be mentioned that the correlation between the two shares is 0.56 and it is significant at $5 \%$ level, which indicates that the states with high share of WOSME in number, like Perils and Kedah, also have higher shares in their VA, though the latter is far less in magnitude.

Thus, it may be suggested that WOSMEs tend to create less VA than the complementary set (men owned SMEs) in respective states, hinting lower end of ventures by WOSME. Also, the correlation between share of SME VA in total business and that by WOSME in total SME is pretty low and insignificant, which probably indicates that VA by men and women owned SME may not cofound with each other in similar states.

However, the productivity, measured by thousand RM per worker shows completely different nature of distribution across the states. This is a possible indicator of the success of SMEs.

Table II posits that though Kelantan, Perils, Kedah remain in the top bracket in terms of VA creation by WOSME, the productivity of the WOSME in these states remains pretty low. The best performer in productivity is $\mathrm{W} P \mathrm{KL}$, followed by Selangor and Palau Penang. Value of fixed asset per worker is highest in Johor, followed by W P KL. 
TABLE Ii Productivity (VA Per Worker) ANd VAlue Of FiXed AsSEt PER WORKER IN WOSME ACROSS STATES

\begin{tabular}{|l|c|c|}
\hline \multicolumn{1}{|c|}{ States } & $\begin{array}{c}\text { Productivity ('000 } \\
\text { RM) per worker }\end{array}$ & $\begin{array}{c}\text { Value of FA ('000 } \\
\text { RM) per worker }\end{array}$ \\
\hline W P KL & 6.667 & 6.94 \\
\hline Selangor & 6.626 & 3.99 \\
\hline Palau Penang & 4.873 & 3.46 \\
\hline W P Putrajaya & 4.007 & 1.87 \\
\hline Melaka & 3.791 & 2.42 \\
\hline Johor & 3.746 & 7.39 \\
\hline W P Labuan & 3.127 & 2.78 \\
\hline Sarawak & 3.107 & 2.50 \\
\hline Perak & 3.077 & 2.94 \\
\hline Sabah & 3.033 & 4.52 \\
\hline Kedah & 2.856 & 2.06 \\
\hline Negri Sembilan & 2.849 & 1.96 \\
\hline Pahang & 2.754 & 4.10 \\
\hline Perils & 2.538 & 1.14 \\
\hline Terengganu & 2.304 & 1.36 \\
\hline Kelantan & 2.101 & 1.15 \\
\hline Source: Analysis of data from Ministry of Statistics 2018, Malaysia \\
\hline
\end{tabular}

Table Iit Productivity (VA Per Worker) And VAlue AdDED ('000RM) IN WOSME ACROSS DIFFERENT CLUSTERS OF STATES

\begin{tabular}{|l|c|c|}
\hline & $\begin{array}{c}\text { Average VA } \\
\text { per WOSME }\end{array}$ & $\begin{array}{c}\text { Average } \\
\text { productivity in } \\
\text { WOSME }\end{array}$ \\
\hline $\begin{array}{l}\text { States with higher GDP per } \\
\text { capita }\end{array}$ & 20.95 & 4.38 \\
\hline $\begin{array}{l}\text { States with lower GDP per } \\
\text { capita }\end{array}$ & 10.53 & 2.80 \\
\hline $\begin{array}{l}\text { States with higher share of } \\
\text { big business with e commerce }\end{array}$ & 16.87 & 3.80 \\
\hline $\begin{array}{l}\text { States with lower share of big } \\
\text { business with e commerce }\end{array}$ & 14.62 & 3.39 \\
\hline $\begin{array}{l}\text { States with higher female } \\
\text { literacy }\end{array}$ & 16.76 & 3.71 \\
\hline $\begin{array}{l}\text { States with lower female } \\
\text { literacy }\end{array}$ & 14.73 & 3.47 \\
\hline \multicolumn{2}{|l|}{ Note: Higher means higher than national average, Source: Analysis of data } \\
from Ministry of Statistics 2018, Malaysia
\end{tabular}

Table III clearly shows that both average VA and productivity per WOSME are significantly higher in states with higher state GDP (more than national average) compared to the lower GDP states. The difference is also there among states with higher shares of big business in ecommerce, though the difference is far lower in magnitude. However, female literacy does not make much of a difference in either VA or productivity. Thus, on the macro level, e commerce facilities and over all GDP of the state make the difference on VA and productivity of WOSME rather than female education.

Further the paper diagnoses the nature and types of distribution of WOSME and SME across micro, small and medium sectors. Ideally this would actually represent the sectoral pyramid (Fig.2) if it followed the plan of the Ministry. As shown in the figure base of the pyramid consists of $18.75 \%$ of all business ventures in services and $15.50 \%$ in manufacturing in micro sector in the country. The prime contribution of this sector is to contribute to employment generation among unskilled or low skilled women. The second tier represents the small sized firms consisting of $2.31 \%$ of business ventures in services and $3.64 \%$ in manufacturing (Table IV) and this is supposed to feed in the big business. This group is an enabler of growth and depends more on the nature of big business. The top tier consists of medium sized WOSME has a very small share in numbers in both manufacturing and services sectors, representing less than $1 \%$ of ventures. They are drivers of growth and would depend more on the nature and style of the SME sector.

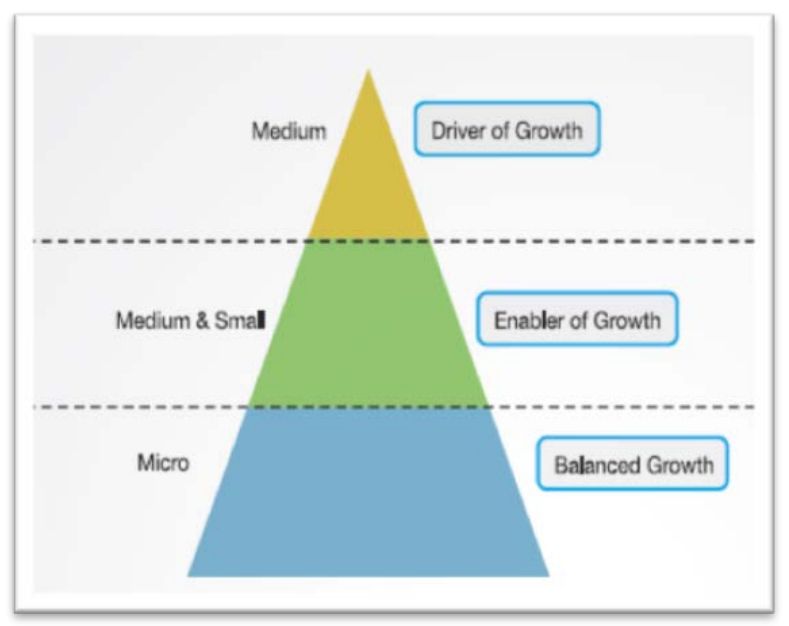

Source: National SME Development Council, 2012

Fig. 2 Role of SMEs in the economy

Table Iv Shares Of Sme ANd Wosme Across Different Size Classes

\begin{tabular}{|c|c|c|c|}
\hline Sector & Micro & Small & Medium \\
\hline \multicolumn{4}{|c|}{ Manufacturing } \\
\hline Share of SME in all business & 44.97 & 47.04 & 5.13 \\
\hline $\begin{array}{l}\text { Share of WOSME in MSM } \\
\text { business }\end{array}$ & 34.69 & 7.75 & 2.74 \\
\hline Share of WOSME in all business & 15.60 & 3.64 & 0.14 \\
\hline \multicolumn{4}{|c|}{ Services } \\
\hline Share of SME in all business & 79.33 & 18.10 & 1.45 \\
\hline Share of WOSME in SME & 23.64 & 12.81 & 7.34 \\
\hline Share of WOSME in all business & 18.75 & 2.31 & 0.10 \\
\hline
\end{tabular}

Theory on entrepreneurial success points out that job creation is a good indicator that reflects not just the financial success of the enterprise, but also how it creates a sustained impact on the economy. In this sense, the entrepreneurs can be divided into two distinct groups: subsistence entrepreneurs who become entrepreneurs as a means of providing subsistence income to the owner, and transformational entrepreneurs who aim innovate to create 
large, vibrant businesses that grow much beyond the scope of an individual's subsistence needs and provide jobs and income for others (Schoar, 2010). However, the vast majority of the micro and small entrepreneurs lie in the subsistence mode, trapped in a "necessity, survival and maintenance" cycle and their activity does not affect national economic development (Acs, 2006). Fig.3 below points out clearly that intensity of job creation tends to be significantly lower in WOSME in Malaysia compared to the overall SME sector, hinting to the fact that among WOSME, the potential to become transformational entrepreneur is far lower.

Though data on WOSME in Table IV represents the similar pyramidal structure as in Fig. 2, it is imperative to look at the presence of WOSME in different size classes in sectors with high-technology quotient and innovation. These sectors not only need better technology and innovation, often they require international digital platform to unleash their full potential. Table $\mathrm{V}$ below points out that in those sectors (highlighted in green), both in manufacture and services, presence of WOSME in medium size class is extremely low or negligible in all SMEs.

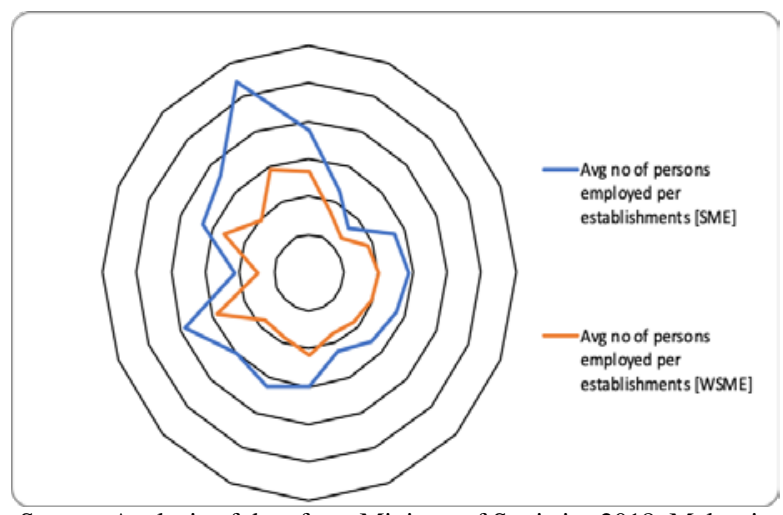

Source: Analysis of data from Ministry of Statistics 2018, Malaysia Fig. 3 Average number of employees employed in SME and WOSME sectors in Malaysia

This means, even if SMEs are present, women entrepreneurs rarely make headway in medium category. In service sector, WOSME has stronger presence of medium firms in food and beverages and real estates, but extremely low representation in information and communication, finance, electricity etc.

Table V Share Of Wosme In Total Sme Across Size-Classes And Sectors

\begin{tabular}{|c|c|c|c|c|}
\hline Sector & $\begin{array}{l}\text { \% of WOSME in } \\
\text { Total SME }\end{array}$ & $\begin{array}{l}\text { \% of WOSME in } \\
\text { Micro SME }\end{array}$ & $\begin{array}{l}\text { \% of WOSME in } \\
\text { Small SME }\end{array}$ & $\begin{array}{l}\text { \% of WOSME in } \\
\text { Medium SME }\end{array}$ \\
\hline Manufacture & 19.96 & 34.69 & 7.75 & 2.74 \\
\hline Manufacture of food products & 29.75 & 44.10 & 14.33 & 3.98 \\
\hline Manufacture of beverages & 13.22 & 19.72 & 10.63 & 0.00 \\
\hline Manufacture of textiles & 26.26 & 37.94 & 11.38 & 0.00 \\
\hline Manufacture of wearing apparel & 66.23 & 71.10 & 22.86 & 6.25 \\
\hline Manufacture of leather and related products & 13.51 & 13.07 & 14.56 & 0.00 \\
\hline Manufacture of paper and paper products & 6.99 & 9.19 & 7.00 & 2.94 \\
\hline Printing and reproduction of recorded media & 10.52 & 12.64 & 8.72 & 3.13 \\
\hline Manufacture of coke and refined petroleum products & 10.28 & 15.79 & 9.33 & 7.69 \\
\hline Manufacture of chemicals and chemical products & 7.97 & 12.45 & 8.10 & 0.00 \\
\hline $\begin{array}{l}\text { Manufacture of basic pharmaceutical products and } \\
\text { pharmaceutical preparations }\end{array}$ & 14.37 & 21.50 & 12.00 & 4.35 \\
\hline Manufacture of rubber and plastics products & 5.36 & 5.36 & 5.97 & 2.08 \\
\hline Manufacture of other non-metalic mineral products & 5.70 & 7.82 & 5.03 & 3.14 \\
\hline Manufacture of basic metals & 3.58 & 3.44 & 3.70 & 3.15 \\
\hline $\begin{array}{l}\text { Manufacture of fabricated metal products, except } \\
\text { machinery and equipment }\end{array}$ & 3.97 & 3.24 & 4.62 & 3.43 \\
\hline $\begin{array}{l}\text { Manufacture of computer, electronic and optical } \\
\text { products }\end{array}$ & 3.90 & 5.79 & 4.10 & 0.88 \\
\hline Manufacture of electrical equipment & 5.37 & 5.49 & 5.74 & 2.86 \\
\hline Manufacture of machinery and equipment & 4.29 & 4.82 & 4.34 & 1.75 \\
\hline Manufacture of motor vehicles, trailers and semi-trailers & 4.15 & 2.63 & 5.17 & 0.00 \\
\hline Manufacture of other transport equipment & 5.34 & 4.69 & 5.93 & 2.56 \\
\hline Manufacture of furniture & 5.71 & 5.39 & 5.96 & 4.90 \\
\hline Other manufacturing & 9.36 & 10.69 & 7.95 & 5.13 \\
\hline Repair and installation of machinery and equipment & 4.90 & 4.59 & 5.02 & 14.29 \\
\hline Services & 21.42 & 23.64 & 12.81 & 7.34 \\
\hline Electricity, gas, steam \& air conditioning supply & 5.13 & 6.82 & 6.88 & 0.00 \\
\hline
\end{tabular}




\begin{tabular}{|c|c|c|c|c|}
\hline $\begin{array}{l}\text { Water supply; sewerage, waste management \& } \\
\text { remediation activities }\end{array}$ & 7.26 & 9.45 & 5.90 & 4.60 \\
\hline Wholesale and Retail Trade & 19.74 & 22.04 & 9.99 & 9.11 \\
\hline Transportation and Storage & 7.13 & 7.11 & 8.78 & 6.09 \\
\hline Accommodation & 13.18 & 17.87 & 9.66 & 6.98 \\
\hline Food and Beverages & 33.55 & 37.03 & 19.59 & 8.00 \\
\hline Information and Communication & 3.28 & 3.47 & 3.28 & 2.04 \\
\hline Finance & 0.86 & 1.22 & 0.15 & 0.00 \\
\hline Real Estate & 6.11 & 5.48 & 9.55 & 13.16 \\
\hline Professional, Scientific and Technical & 12.12 & 12.96 & 11.10 & 7.71 \\
\hline Administrative and Support Service & 13.79 & 14.87 & 11.98 & 11.78 \\
\hline Education & 45.69 & 51.93 & 28.98 & 9.25 \\
\hline Health and Social Work & 31.65 & 36.66 & 17.92 & 15.79 \\
\hline Arts, Entertainment and Recreation & 11.67 & 13.52 & 6.45 & 3.59 \\
\hline Personal Services and Other Activities & 28.43 & 27.70 & 40.13 & 37.76 \\
\hline
\end{tabular}

Note: Grey coloured sectors represent higher technology quotient
Source: Analysis of data from Ministry of Statistics 2018, Malaysia

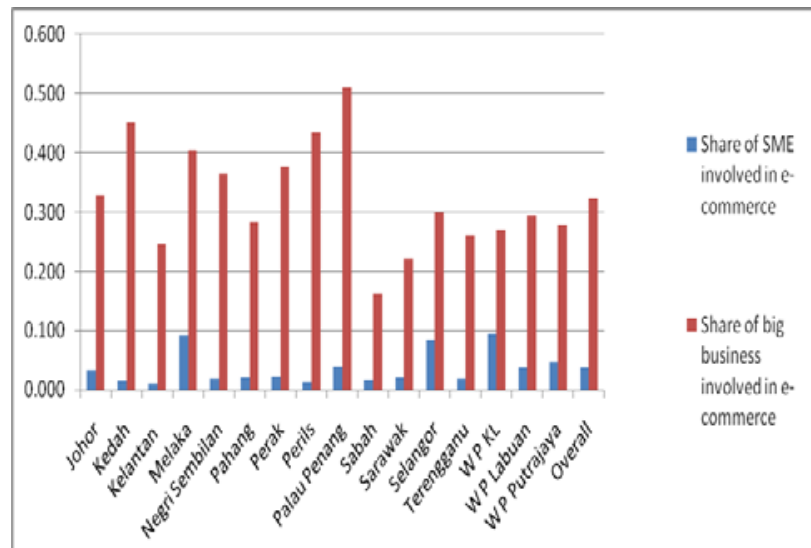

Source: Analysis of data from Ministry of Statistics 2018, Malaysia Fig. 4 Involvement in e-commerce in SME and big business across states in Malaysia

Finally, we look into the share of SME and big business in e-commerce. Fig.4 represents that understandably big business is far more involved in e-commerce and hence they are integrated in digitalized platforms. The best state in this respect is Palau Penang. However, for SME, the integration is best found in Melaka and $\mathrm{KL}$ and the overall correlation between these two is highly insignificant across states. The fact that overall SME sector is still far less involved in ecommerce and its involvement is not determined by digitalization in big business suggests that there is still high scope for them. No specific information of e-commerce involvement among WOSME is obtained. It cannot be denied that the WOSME who are major value generators are more global actors operating on the digital platform. Our evidence collected from personal interview with ten iconic women SME owners in Malaysia point out that $80 \%$ of them have very strong presence in digital platforms, including e-commerce. They innovate their products for personalized needs of their clients, primarily using hightech inputs, thus avoiding hiring too many workers and also too much heavy machinery. These women succeed with their digital power, breaking the shackle of input-intensity of either labour or capital. Therefore, an attempt at estimating the influencers of VA by WOSME through regression shown in Table VI, which considers share of both large and small enterprises engaged in e-commerce, besides traditionally expected variables like overall state economic condition, ethnicity of the majority population etc.

TABle Vi Regression Results On Va Per Enterprise Of Wosme

\begin{tabular}{|c|c|c|c|c|}
\hline VA of WOSME & Coef. & $\begin{array}{l}\text { Std. } \\
\text { Err. }\end{array}$ & $\mathrm{t}$ & $\mathrm{P}>\mathrm{t}$ \\
\hline $\begin{array}{l}\text { Share of SME in } \\
\text { ecommerce }\end{array}$ & 0.32 & 0.45 & 0.69 & 0.53 \\
\hline Fixed asset per WOSME & 0.18 & 0.10 & 1.83 & 0.14 \\
\hline $\begin{array}{l}\text { Share of big business in } \\
\text { ecommerce }\end{array}$ & $0.29 * *$ & 0.12 & 2.37 & 0.05 \\
\hline $\begin{array}{l}\text { Share of ICT usage in } \\
\text { business }\end{array}$ & 0.00 & 0.00 & 0.70 & 0.52 \\
\hline $\begin{array}{l}\text { log of V.A per } \\
\text { establishment by big } \\
\text { business }\end{array}$ & -0.06 & 0.04 & -1.38 & 0.24 \\
\hline $\begin{array}{l}\text { Share of business involved } \\
\text { in Innovation }\end{array}$ & 0.00 & 0.00 & -0.78 & 0.48 \\
\hline $\begin{array}{l}\text { Chinese population share } \\
\text { in state }\end{array}$ & $-0.29 * *$ & 0.11 & -2.61 & 0.05 \\
\hline State share in GDP & $0.04 * *$ & 0.01 & 4.02 & 0.02 \\
\hline Incidence of poverty & 0.01 & 0.01 & 0.91 & 0.41 \\
\hline log of GSDP per capita & 0.19 & 0.07 & 2.89 & 0.05 \\
\hline Constant & $0.82 * *$ & 0.30 & 2.77 & 0.05 \\
\hline F statistic & \multicolumn{4}{|c|}{$39.33 * * *$} \\
\hline $\mathrm{R}^{2}$ & \multicolumn{4}{|c|}{0.98} \\
\hline
\end{tabular}

Source: Analysis of data from Ministry of Statistics 2018, Malaysia

The regression analysis attempts to locate whether the average VA of WOSME is dependent more on nature of big 
business of the state (complement of share of big business in e-commerce) or on the characteristics of SME sector itself in general. Also, it is of relevance to throw light upon the level of economic and demographic factors determine the VA of WOSME. It is generally believed that the people with Chinese origin are far more enterprising and hence states with more Chinese population might push better success of WOSME. In this regression results, it is clear that neither share of SME in e-commerce nor the fixed asset of WOSME control the VA significantly. On the other hand, it is observed that share of big business involved in $\mathrm{e}$ commerce in the state facilitate the VA of SME, representing stronger synergy between big business and WOSME. The state specific variables like share of GDP in the state (state share in GDP), share of Chinese population in total state population and logarithm of state GDP are better correlates of VA in WOSME. As expected, the overall economic condition of a state, reflecting the overall infrastructure of the region, positively affects the VA. However, share of Chinese population negatively controls it. This result might have occurred because the non-Chinese Malays have far better access to credit from public sources which make them successful in small business. This may be corroborated by secondary information that there are many government loan schemes specifically made available to assist Bumiputera SMEs such as TEKUN, Skim Pembiayaan Mudah Jaya (SPiM), New Entrepreneur Fund (NEF). To achieve the 20 per cent target for Bumiputera SMEs, a programme called TERAS was launched in 2010 under the umbrella of TERAJU (Unit Peneraju Agenda Bumiputera), a unit under the Prime Minister's Department. TERAS aims to increase Bumiputera SMEs that will scale up these enterprises, accelerate their growth and enable them to compete in the liberalized economy without over dependence on the government (Chin \& Lim 2018) [1]. The focus is primarily on micro and small business with potential. Also, due to their strong connection in business world, people with Chinese origin might get involved more in to bigger ventures.

Table VII Regression results on Productivity (VA per employee) of WOSME

\begin{tabular}{|l|c|c|c|c|}
\hline \multicolumn{1}{|c|}{ Productivity in WSME } & Coef. & Std. Err. & t & P>t \\
\hline $\begin{array}{l}\text { Share of SME in } \\
\text { ecommerce }\end{array}$ & $0.10^{*}$ & 0.05 & 1.96 & 0.09 \\
\hline Fixed asset per WSME & 0.01 & 0.01 & 0.96 & 0.37 \\
\hline $\begin{array}{l}\text { Share of big business in } \\
\text { ecommerce }\end{array}$ & $0.04^{* * *}$ & 0.01 & 3.46 & 0.01 \\
\hline State share in GDP & $0.01^{* * *}$ & 0.00 & 6.64 & 0.00 \\
\hline Incidence of poverty & $0.01^{* *}$ & 0.00 & 2.72 & 0.03 \\
\hline $\begin{array}{l}\text { log of GSDP per capita of } \\
\text { state }\end{array}$ & $0.02^{* *}$ & 0.01 & 2.36 & 0.05 \\
\hline log of VA in big business & 0.01 & 0.01 & 0.64 & 0.54 \\
\hline Constant & 0.09 & 0.04 & -2.60 & 0.04 \\
\hline F statistic & \multicolumn{5}{|c|}{$41.48^{* * *}$} \\
\hline $\mathrm{R}^{2}$ & 0.97 \\
\hline \multicolumn{4}{|c|}{ Source: Analysis of data from Ministry of Statistics 2018, Malaysia } \\
\hline
\end{tabular}

AJMS Vol.8 No.3 July-December 2019
Similar regression on productivity of WOSME too finds the similar trend: it depends on share of big business in ecommerce and a host of economic and demographic factors of the concerned state. Additionally, it has another new correlate, share of SME in e-commerce (Table VII). Looking at its low statistical significance, it may be inferred that productivity is weekly controlled by e-commerce linkages among SME.

Since both the VA by and productivity of WOSME appears to be significantly influenced by share of big business in ecommerce, it may be a clear indication that big business in large sector not only pushes higher productivity but also generates more value by WOSME. This may be explained by the evidence of predominant middle block in triangleenablers of big business. Additionally, it is observed that the focus of SME on e-commerce leads to increased productivity. This may be explained by lower inputs in terms of remuneration of women entrepreneurs with higher technology skills whose cost of education (positive externalities) is more of a notional factor. What remains unexplored in this study is the differential in remuneration for technical and non-technical women employees or gender differentials due to data constraint.

\section{CONCLUSION}

In conclusion, the WOSMEs appear to have a strong presence in overall SME sector of Malaysia. However, their dominant presence is observed in low-technology traditional sectors like food, beverages, hospitality, wearing apparels, wholesale retail trade etc. These traditional SMEs also hire less number of workers compared to the overall SME sector, indicating less inclusion of population than expected. Majority of WOSME seem to be shackled by chains of subsistence entrepreneurship and rarely emerge as transformational entrepreneurs. The observation about the share of big business in e-commerce and state share in GDP driving financial success of SME, captured by value added and productivity of WOSME, is an important indication of inequality. Therefore, the authors argue that the economically advanced states, with pre-dominantly ecommerce based big business, provide the economic and technical infrastructure that supports success of WOSMEs, possibly in the form of backward and forward linkages. The presumption here is supported by primary data collected through interviews by the authors. The skewness of the states with urban proximity, higher economic development being home to successful WOSME is an inherently traditional developing country phenomenon. Thus with all its potential and strengths, WOSME in Malaysia still fall short of reaching the status of game changer: constrained in pushing the growth of this resource-rich highly educated country. They remain good engine for growth of big business, rather than pushing the economy forward by themselves. Unfortunately, this finding reconfirms the lack of inclusiveness in developmental initiatives which may be substantiated by the fact that states with lower GDP have low productive WOSME, though large in presence by 
numbers. This brings the research to the much reiterated policy criticism that the state initiatives remain cloistered in the more able states / regions and disparate: special vehicles of delivery is the missing link required for the last mile connectivity to the poorer regions that are unreached. Also, there seems to be complete absence of policy framework focused on women to encourage high potential WOSME to break the glass ceilings of low-technology traditional sectors and usher into a new phase of growth and inclusiveness enhancing vibrant sector.

\section{ACKNOWLEDGEMENT}

The study is part of the project Sustainable Economic, Social and Political Empowerment of Women through Small and Medium Enterprises (SMEs): Strategic Learning from South \& South East Asia, sponsored by UPE 2 of University of Calcutta under UGC, India. We also express our heartiest gratitude towards our associates in Malaysia.

\section{REFERENCES}

[1] Chin, Y.W., \& Lim, E.S. (2018). SME Policies and Performance in Malaysia. ISEAS Yusof Ishak Institute, 3

[2] Daño-Luna, M., Canare, T., \& Francisco, J.P. (2018). Drivers of Philippine SME Competitiveness: Results of the 2018 SME Survey. SSRN Electronic Journal, 10.2139/ssrn.3299885.

[3] Department of Statistics, Malaysia. Retrieved from https://www. dosm.gov.my/v1/

[4] Dutta, A., \& Banerjee, S. (2018). Does microfinance impede sustainable entrepreneurial initiatives among women borrowers? Evidence from rural Bangladesh. Journal of Rural Studies, 60, 70-81.
[5] Eurostat (2014). Patent Statistics at Eurostat. Mapping the contribution of SMEs in EU patenting. Eurostat Manuals and Guidelines, Luxembourg. Retrieved from http://ec.europa.eu/eurostat/ documents/3859598/6064260/KS-GQ-14-009-EN-N.pdf/caa6f46711f8-43f9-ba76-eb3ccb6fab6d in May 2019

[6] GEM Consortium 2012. Global Entrepreneurship Monitor. Retrieved from https://www.gemconsortium.org/report

[7] IFC (2010). Scaling-Up SME Access to Financial Services in the Developing World. International Finance Corporation, World Bank Group, Washington D.C. Retrieved from http://www.enterprisedevelopment.org/wp-content/uploads/ScalingUp_SME_Access_to_ Financial_Services.pdf.

[8] National SME Development Council, Malaysia (2012). SME Masterplan 2012-2020. Retrieved from https://www.slideshare.net/ MIBMagazine/malaysia-sme-masterplan-2012-2020-the-gamechanger in May 2019

[9] OECD (2013). SME and Entrepreneurship Financing: The Role of Credit Guarantee Schemes and Mutual Guarantee Societies in supporting finance for small and medium-sized enterprises. OECD Working Party on SMEs and Entrepreneurship. Retrieved from https://one.oecd.org/document/CFE/ SME(2012)1/FINAL/en/pdf in May 2019

[10] OECD (2016). Fostering Markets for SME Finance: Matching Business and Investor Needs. OECD Working Party on SMEs and Entrepreneurship. Retrieved from https://one.oecd.org/document/ CFE/SME(2016)4/FINAL/en/pdf in May 2019

[11] OECD (2017). Enhancing the Contributions of SMEs in a Global and Digitalized Economy. Meeting of OECD Council at Ministerial Level, Paris, 7-8 June. Retrieved from https://www.oecd.org/mcm/ documents/C-MIN-2017-8-EN.pdf

[12] Rankin, K.N. (2002). Social Capital, Microfinance, and the Politics of Development. Feminist Economics, 8(1), 1-24.

[13] Schoar, A. (2010). The Divide between Subsistence and Transformational Entrepreneurship. Innovation Policy and the Economy, University of Chicago Press, 10(1), 57-81.

[14] US Census Bureau (2014). https://www.census.gov/programssurveys/acs/guidance/comparing-acs-data/2014.html. 